This item was submitted to Loughborough's Research Repository by the author.

Items in Figshare are protected by copyright, with all rights reserved, unless otherwise indicated.

\title{
Performing the 'fun' self: how members of the Red Hat Society negotiate cultural discourses of femininity and ageing
}

PLEASE CITE THE PUBLISHED VERSION

http://dx.doi.org/10.1177/1367549413484306

PUBLISHER

(c) Sage

VERSION

AM (Accepted Manuscript)

LICENCE

CC BY-NC-ND 4.0

\section{REPOSITORY RECORD}

van Bohemen, Samira, Liesbet van Zoonen, and Stef Aupers. 2019. "Performing the 'fun' Self: How Members of the Red Hat Society Negotiate Cultural Discourses of Femininity and Ageing". figshare.

https://hdl.handle.net/2134/13283. 
This item was submitted to Loughborough's Institutional Repository (https://dspace.lboro.ac.uk/) by the author and is made available under the following Creative Commons Licence conditions.

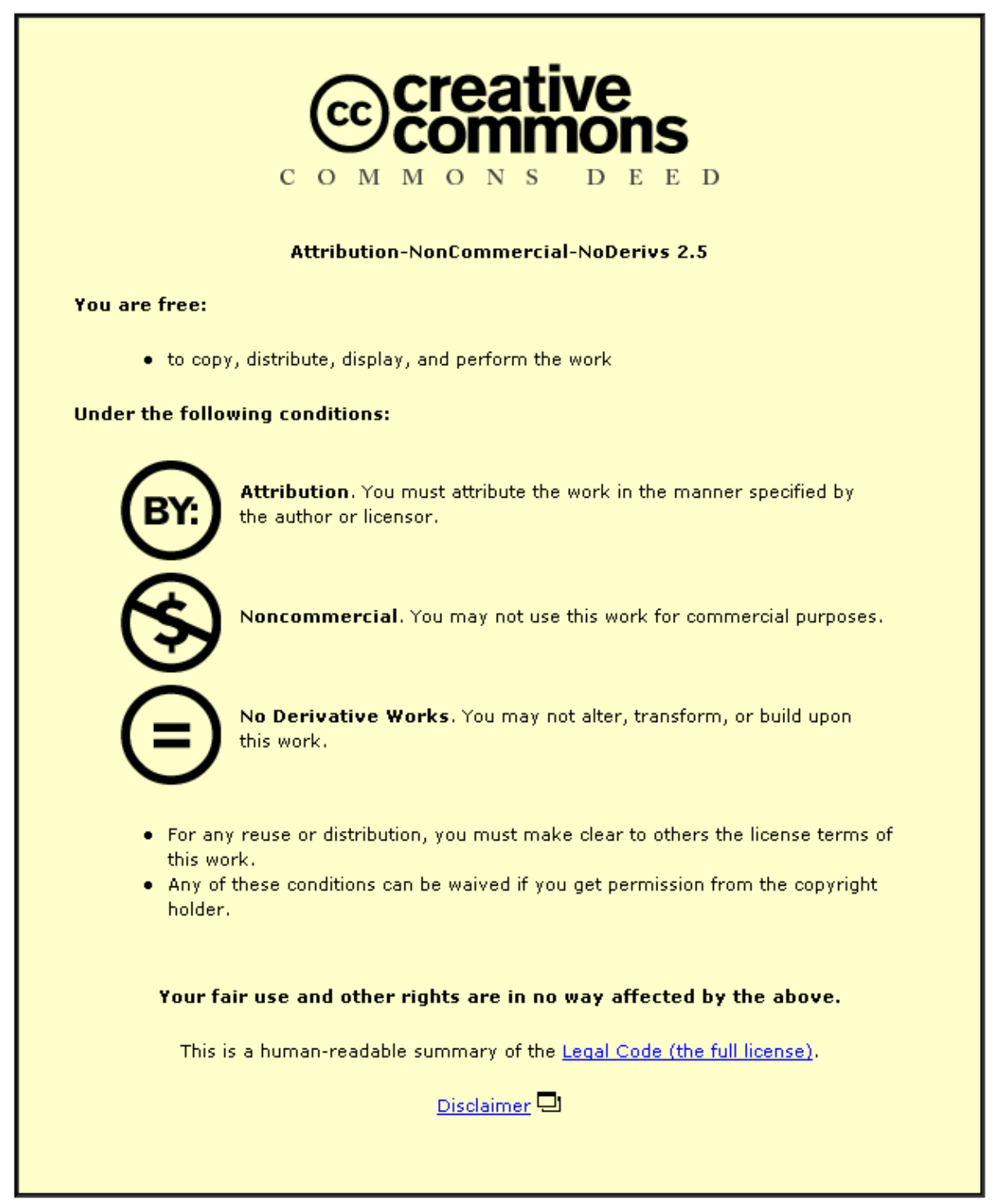

For the full text of this licence, please go to: http://creativecommons.org/licenses/by-nc-nd/2.5/ 


\title{
Performing the 'Fun' Self
}

\section{How Members of the "Red Hat Society" Negotiate Cultural Discourses of Femininity and Ageing ${ }^{1}$}

\author{
Samira van Bohemen \\ Phd-student at the Department of Sociology Erasmus University Rotterdam \\ Liesbet van Zoonen
}

Professor of Media and Communication at the University of Loughborough and at the Erasmus University Rotterdam

Stef Aupers

Associate professor at the Department of Sociology Erasmus University Rotterdam

Contact First author:

Erasmus University Rotterdam

POBOX 1738

3000 DR Rotterdam

The Netherlands

Email: vanbohemen@fsw.eur.nl

Tel: $+31(0) 10-4082085$

\footnotetext{
${ }^{1}$ The authors would like to thank Nadine Raaphorst for her invaluable work in transcribing the interviews used in this article.
} 


\begin{abstract}
Since its foundation in 1998 the "Red Hat Society" (RHS) has become a popular international movement of women over fifty that is known for its distinct group performances. Red Hatters show up in public spaces wearing red hats, purple clothing and - sometimes - red gloves, and engage in various fun and frivolous activities. Previous studies about the RHS have found that the RHS's main appeal is that it creates an escape from women's day-to-day life experiences. Such outcomes, however, ignore the fact that the RHS's appeal is also motivated by the particular life histories of its members. To explore the relevance of these life histories, we conducted interviews with RHS members in the Netherlands. Our findings indeed show that to understand the cultural meaning of the RHS it is necessary to include a diachronic dimension in the research, articulating members' current negotiations of femininity and aging with those of their past.
\end{abstract}

Key words: Red Hat Society; fun; celebration; gender negotiation; identity performance; coping; life histories. 


\section{Performing the 'Fun' Self}

\section{How Members of the 'Red Hat Society' Negotiate Cultural Discourses of Femininity and Ageing}

\section{Introduction}

When in 1998 a handful of fifty-something women from Fullerton California went out for tea, none of them expected this to mark the birth of an incredibly popular and worldwide phenomenon. The friends all wore the red hat that one of them, artist Sue Ellen Cooper, had given them as a birthday present. Later that year they decided to launch an official organisation, the 'Red Hat Society' (RHS). With their signature statement that 'there is fun after fifty' the Red Hatters quickly made their way into all fifty US states and into various other countries, including Australia, the United Kingdom and the Netherlands, the latter having the highest density of Hatters in the world. ${ }^{1}$ The RHS is known for their distinct group performances: its members show up in public spaces wearing red hats, purple clothing and (occasionally) red gloves, while engaging in various fun and frivolous activities.

Because of its size and spread - there are over 20,000 chapters in the US alone the RHS is one of the largest women's groups in the world. Yet, to date, only a few academic studies have been conducted on the RHS and they focus exclusively on branches in the United States. These studies approach the RHS from two distinct perspectives of individual well-being on the one hand, and gender performance on the other. Respectively, they have interpreted participation in the RHS as a coping resource 
(e.g., Hutchinson et al., 2008) and as a negotiation of dominant cultural discourses on femininity and aging (e.g., Stalp et al., 2008; 2009). In this paper we will add to this body of literature in several ways. First, empirically, we will focus on a non-US collection of Red Hatters, that is those in The Netherlands. Second, we will add to the two existing perspectives with a further exploration of the 'fun' factor and how this is experienced and performed by Red Hatters. Third, we will examine whether and how the possibilities that the RHS offers to negotiate dominant notions of femininity and age are articulated with specific and situated life histories of its participants. In order to explore these three aspects of the RHS we conducted in-depth interviews with individual members in the Netherlands, and participated in a number of their events. ${ }^{2}$

In the remainder of the paper, we will first provide a brief description of the RHS movement, its origins, goals and composition. This will be followed by a review of previous studies on the RHS in the US. We will then explain our research design and present our main findings. The paper is concluded with a discussion of the theoretical implications of our results for other studies on gender and identity performance.

\section{Birth of an International Women's Society}

The 'official' history of the RHS, as it is told on its US national website, is that it was the result of an impulse buy of Sue Ellen Cooper who stumbled over a vintage red hat at a thrift shop and bought it simply because it was cheap. She began to give red hats as a birthday gift to her friends who (reluctantly) turned fifty or older. With the hat she enclosed a poem called 'Warning' by English poet Jenny Joseph (1961), which reads:

When I am an old woman I shall wear purple, 
With a red hat which doesn't go, and doesn't suit me,

And I shall spend my pension on brandy and summer gloves,

And satin sandals, and say we've no money for butter.

The hat and the poem formed the inspiration for the Red Hat Society, which grew into an international movement that offers 'fun' and 'friendship' for women over fifty. By 2010 the RHS, according to the official website, consisted of more than 20,000 chapters in more than 25 different countries.

Other than fun and friendship, the RHS does not claim to have specific objectives. The US mother organisation explicitly denounces political involvement of any kind. It prefers to refer to itself as a dis-organisation that imposes no other rules than the dresscode and the request to honour the motto of having a 'fun' time. To this end Red Hatters organize all kinds of leisure activities, ranging from dinners, tea parties, historical walks and museum visits to golfing tournaments, belly dancing classes and even trips to foreign destinations. In practice the RHS exists of a large amount of locally organized suborganizations, called 'chapters' that organize such events for their members. Each chapter is led by a 'Queen' who takes care of the daily responsibilities. The international conglomeration of all chapters is held together by websites, online networks, newsletters and yearly international and national meetings.

In order to become a member women can join an existing chapter in their area or start their own and become 'Queen'. New Queens need to officially register their chapter with the US organisation, called 'Hatquarters'. Events are mostly local, but occasionally also organized nationally. In both cases the events are announced on RHS websites. During RHS events all members are required to wear red hats and purple clothing. 
However, when a member is celebrating her birthday in the same month as the event she is expected to reverse the colour pattern, wearing a purple hat with red clothing. Sometimes Hatters accessorize their already exceptional attire with red gloves and boas. Women who are not yet fifty are also allowed to join but are required to wear pink hats and lavender clothes, until their REDuation. ${ }^{3}$

The Netherlands accounts for almost 100 chapters, which are spread over the country (see Appendix 1). The Dutch branch emerged in 2005 following a newspaper article and expanded rapidly. ${ }^{4}$ As can be seen on the map in Appendix 1 the chapters that thus emerged are dispersed over both the big cities and smaller villages of the Netherlands. No systematic pattern can be discerned in the distribution of chapters over the country, though there is some clustering in the area with the highest population density ('Randstad'). Some of these chapters are small with some ten members or less, others are very large and have over fifty members. Chapters emerge and disappear frequently, because of internal conflicts, separation or because things simply do not work out and members quit. This is also a reason why some of the cities and villages have more than one chapter. 5

\section{Psychological and cultural perspectives}

In the US three groups have conducted research about the RHS. Their studies address the RHS's relation with play (Yarnal, 2006; Yarnal et al., 2008), dress-up (Yarnal et al., 2011), conspicuous consumption (Stalp et al., 2009), and older women's psychosocial health and well-being (Hutchinson et al., 2008; Radina et al., 2008; Son et al., 2007). Two general and somewhat overlapping approaches - one psychological, the other more 
cultural - to RHS membership and participation can be discerned that suggest that membership of the RHS involves more than 'fun' and 'friendship'. In the first the RHS is positioned as a coping resource that advances members' well-being and quality of life. In the second, the RHS is understood as a public negotiation of dominant cultural discourses on femininity and older women.

\section{The RHS and Individual Well-Being}

Research in which the RHS is approached as a coping mechanism for changing life conditions, starts from the assumption that as women grow older they are often confronted with high levels of stress, due to, for instance, the loss of social relations, the death of spouses, illness or social isolation (Hutchinson et al., 2008; Son et al., 2007), but also as a result of a negative stereotyping of older women in society (Radina et al., 2008). Such studies argue that the RHS enables women to cope with such stress, because it provides a context for both the formation of social relationships and for positive emotions. Building on psychological theory that highlights the importance of positive emotions in overcoming personal hardship, these studies conclude that RHS participation can be 'linked to higher levels of socio-emotional, psychological, and physical health' for midlife and older women in Western society (Son et al., 2007: 100-101). Such findings are generally based on textual data collected in open-ended survey-questions, asking respondents to share stories about their experiences as Red Hatters.

Overall, these studies advance the idea that leisure is pivotal to an individual's well-being and life satisfaction. In the case of the RHS this involves gaining access to a system of social (instrumental as well as emotional) support (Sun et al., 2007; Hutchinson 
et al., 2008; Radina et al., 2008), and an opportunity for women to disengage from their day-to-day lives and reassess life priorities and circumstances in a positive manner (Yarnal, 2006; Radina et al., 2008). According to the researchers, more generally, play functions as a liminal space that is both socially and culturally separate from daily life, which creates the opportunity to negotiate individual problems and identities. For the RHS this is also tied in with dress-up practices that signify a clear demarcation with daily life activities and experiences. Yarnal et al. (2011), for instance, claim that individual Hatters come to adopt a more positive sense of self and a more favourable view on their lives by dressing-up in the vibrantly coloured clothes.

Hence, these studies suggest that Red Hatters' engagement in various activities helps them to construct, experience and perform a personal identity that is distinct from everyday life and that - in turn - helps them to cope with whatever problems they may be faced with. Such individual coping, however, also has wider cultural relevance, as it involves a public performance of femininity that sets Red Hatters apart from mainstream gender discourse.

\section{The RHS and the Negotiation of Gender Discourse}

Gender discourse and its negotiation by the RHS are explored in the second set of existing studies. Following the work of Judith Butler (1988; 1990), it is argued in these studies that gender is a repetitive performance that constructs dichotomous gender categories through which individuals understand themselves. As a result, gender is always open to negotiation and resistance and Red Hatters are seen - in these studies - as an exemplary case of such negotiation. Stalp et al. (2008; 2009), for instance, argue that 
Red Hatters undermine traditional gender discourse of midlife and older women through conspicuous consumption and a public exhibition of fun and camp.

The researchers in this 'tradition' have mostly conducted ethnographic research, and describe members' conduct during social events as an exaggerated display of femininity with many built-in contradictions. For example, Stalp et al., $(2008,2009)$ show how the activities characteristically performed by the RHS, such as lunches, tea parties and shopping frenzies, in general are considered hyper-feminine. Yet, much of the behaviour of the Red Hatters simultaneously resists traditional femininity, by, for instance, being loud in public and wearing over-the-top clothes (red hats, purple dresses and an occasional red glove), in off colours. Stalp and her colleagues therefore conclude that with this exaggerated display of femininity, intended to draw a crowd, Red Hatters both challenge and reify dominant cultural expectations of proper behaviour for middle aged and older women. 'RHS members are dressed in ultra-feminine ways, and are acting in stereotypically less than feminine ways as they claim public space, make noise, and command public attention.' (Stalp et al., 2009: 239).

Again leisure is constructed as having wider meanings than simply spending spare time, though in this case because of its function as a bearer of cultural meanings rather than of individual ones. It is argued that leisure is contradictory with the general image of women as caretakers, who as mothers and wives go through life providing for others (Yarnal, 2006; Stalp et al., 2008). Hence, the RHS's main appeal according to these studies is the escape from women's traditional responsibilities. In addition, the male gaze, commonly not focused on women over fifty is reclaimed, and Red Hatters gain abundant 
attention from men when parading in their regalia (cf. Stalp et al., 2008; 2009; Yarnal, 2006; Yarnal et al., 2011).

In sum, what is argued in these cultural studies on the RHS is that the playful leisure space Red Hatters create during their activities, offers them not just solace for personal problems and individual hardship. It provides the opportunity to negotiate the rules of the dominant cultural order - in terms of gender and aging. This is brought about by a performance of self that is distinct from daily life and produces an (temporary) escape from it.

\section{Dutch Red Hatters, fun and life histories}

While the two lines of research discussed here are distinct in their psychological and cultural approaches, focusing on individual and cultural meanings respectively, they share their assumption that at fifty - more or less - life changes for women in problematic ways and that the RHS offers a relatively unproblematic set of practices to negotiate these problems. Both assumptions seem somewhat limited and construct the Red Hatters as either 'coping' with past hardship or 'fighting' sexist and ageist stereotypes. The question as to how the RHS members experienced their lives before their fiftieth birthday remains open, as does the question of what exactly makes Red Hat membership pleasurable, and what constitutes 'fun'. In addition, it seems necessary to examine whether psychological and symbolic meanings attributed to Red Hat membership are specific to the US, or take a different form in a country with a gender 'culture' that has been shown to be thoroughly distinct from the US (see Hofstede, 1984). 
To investigate national particularities of Red Hat membership, examine how pleasure and fun are articulated, and whether particular life experiences lead to Red Hat membership, we take a 'life histories' approach in which both past and present individual experiences of hardship, exclusion and fun are brought to bear upon the RHS performances of femininity.

\section{Research Approach}

We conducted long in-depth interviews with 14 members of different RHS chapters located throughout the Netherlands (11 Queens and 3 regular Hatters). We also participated in Red Hat events, although these observations are used here for further illustration mainly, not as objects of study in themselves (for more information see endnote 2). The interviews were semi-structured and lasted between one and a half and four hours. Each interview consisted of two parts. The first part dealt with how respondents view their involvement in the RHS, and we asked them (amongst other things) about the pleasures they derived from being a Red Hatter and what meaningful experiences they have had through their RHS membership. Because performance is contingent on group dynamics, we also asked questions on how Red Hatters view their relations with other group members and with their 'audiences'. The second part of the interview dealt with the life histories of members, asking about significant life events, such as going to school, friendships, marriage, childbirth, illness, but also about the role of aging in society. Furthermore, we asked respondents to reflect on their youth, the family and the environment they grew up in. 
We approach the respondents' stories as simultaneously reflective and constructive, which means analyzing the interviews at two levels: at the level of information about particular experiences and feelings and - at the same time - at the level of identity performance (cf. Van Zoonen, 1994). Chase (2005: 656) speaks in a similar vein of life histories as 'retrospective meaning making - the shaping or ordering of past experience' in which the self and reality are performed. In analyzing the interviews we looked for recurring themes, which were coded and placed into a data matrix. Codes were derived by employing an inductive and comparative method (Glaser and Strauss, 1967). We compared interview fragments, paying particular attention to both recurring similarities and differences, in order to reach saturation of discourse. Furthermore, we constructed mini-biographies in order to show how our respondents' life histories intersect with RHS performance (Brannen and Nilsen, 2011). These mini-biographies are constructed from much larger narratives of past experiences obtained during interviews, which cannot be presented here in full because of their length. We did not anonimize the data, because all women we interviewed liked to share their experience and were proud to be in the public eye as Red Hatters.

\section{Results}

In our interviews, we heard some stories of the RHS being a source of new friendships, comfort and coming to terms with aging. We also heard stories of the pleasure of attracting the attention of the crowd and disrupting stereotypes of older women. In many ways, our results thus mirror those of previous research on US collections of Hatters. Yet, the interviews also made clear how particular life histories fed into the appeal of the RHS 
and how fun was experienced. In the next sections we will examine the meaning of fun for the Dutch Red Hatters, and then present two mini-biographies that show how and why different life histories also inspire different meanings to being a Red Hatter.

\section{Liberating the 'fun' self}

The Red Hatters in our study generally expressed that they are experiencing their favourite period in life, even if some Hatters at the time did also struggle with major challenges, such as serious illnesses of their own or their relatives. Still, they maintained that the coming of age has its so-called benefits. Annette is one of the first wave Red Hatters in the Netherlands, who met us wearing a red buntal hat on top of a purple jacket and knee length red skirt. Her lipstick and her shoes were red as well. She says: 'Yes, age. I am 62 now, I mean, yes I am, it is just fun. I mean, I think somehow there are some advantages to being older, let's put it like that.'

Like Annette, other Red Hatters say that the bright side of life needs to be celebrated. They often suggest that life after fifty has come with an awareness and acceptance of life's flaws, and with a sense of ease about their own proclaimed imperfections. Our respondents often saw themselves failing at being considered nice by everyone, while they also felt pressured to fulfil the double standard of being successful, while at the same time maintaining good and loving relationships with relevant family members. Both Clema and Corrien, tell their stories in such terms. Clema had a newspaper article about the RHS stored in her closet for more than six years, before she joined only recently. She showed us her first red hat, wide-brimmed with some flower decoration, and explained: 
Clema: 'It is actually quite comfy to be older. Girl [addressing SvB], at your age there is still so much you need to do. You are working on your future, and you want a good relationship, don't you, you want to become a good mother, you want to make your own money. Unconsciously you have so many goals in your mind. Whereas we feel like ... I don't have to prove myself anymore, that's over and done with, I don't feel like that, I just want to do fun things.'

Corrien, a Red Hatter with a thing for little knick-knacks expresses similar feelings when she says:

Corrien: 'After my fiftieth birthday, I think that I started to live more consciously, and this is also due to certain situations you have been confronted with. And that's why you think 'it can be over in a blink.' So you want to get more out of life than you did before. (...) And don't have to fulfil certain expectations. (...) And that's just nice when you think 'what do I care if everyone likes me or not,' and that is liberating.'

Clema and Corrien recount experiences of constraint and liberation. Other Red Hatters too, say that expectations of being a 'good' woman have held them back in fully enjoying life. In some cases, our respondents claim, with hindsight, that it was actually quite 'silly' that they found the opinions of others so important. Martine who noted that she 'always wanted to please and that other people liked me' agrees with Corrien who claims that 'it's actually ridiculous that you have felt this way.' Hence Hatters infer that now they are past fifty, they can leave such anxieties behind and allow themselves to do what they want instead, to only do 'fun' things. 
This emphasis on 'fun' expresses itself both in the practices of the Red Hatters, and the way they organise themselves. It already starts at home where they dress-up in vibrant colours, then they go out in public, meet each other, wave to bystanders, pose for pictures and laugh. With national and other big events some spontaneous singing and dancing usually occurs as well, sometimes with musical guidance from their own personal choir Redtekehat. ${ }^{6}$

Through such practices, the RHS gives a platform to perform this new stage in life and celebrate the 'fun' self. With the motto that 'silliness is the comedy relief of life' (Cooper, 2004), the idea of 'fun' just for 'fun's sake is itself very much embedded in the RHS. $^{7}$ This idea also finds expression in the organisation's reference to itself as a disorganisation, which has no rules. Many Red Hatters find this pleasurable:

'You know, there is so much you need to do in life; you need to get up in time, go to work, but before that, you need to shower, dress, brush your teeth, have breakfast, otherwise you cannot leave home. You need to play by the rules in the office, at work; there is someone above you and you need to do what that someone says, you need to talk to so-and-so. And we do not need to do anything, we just do what we like. And if you don't want to join, or do not feel like something, then you don't need to do anything. That is allowed! And that is what I like.'

Some Hatters, however, temper this belief. Joyce, a tall woman who makes her own hats and clothes and likes to dress completely over the top in shiny purple combined with red pantyhose, for instance, says: 
'An organisation without rules doesn't exist. And this also goes for the RHS (...). The Red Hatters started with the rule [that] you wear a red hat and purple clothing. So they already started with a rule. So there are rules'

Nevertheless, all Hatters generally greet the 'no-rules-rule' with great enthusiasm. They also frequently stress that they are not about charity, or good causes, and denounce complaining about personal problems. Janna, who as a Hatter wears elegant widebrimmed hats, notes, for instance:

Janna: 'The nice thing is, you don't have any obligations. It's just $\operatorname{cosy}^{8}$, it's gay, we are not going to nag, and you don't get the chance to go on for hours about all your illnesses or other stuff. We have known each other for quite some years, of course, so you do ask how things are, but you cannot go on for half a night. It's just, we have an uncomplicated evening, and if you want to talk, you can talk about easy things; everyone has their problems and you can leave them home that night.

Within the RHS this liberation of the 'fun' self is typically embedded in a playful performance of what one might call 'radical femininity'. Red Hatters catalogue themselves as queens, duchesses and ladies. Moreover, their overly feminine dress-style red and purple clothing, hats, gloves, boa's and other ornaments - is meant to draw public attention. As such, their performance is conducive to the visual pleasure of others, but it is also what the Red Hatters we interviewed generally draw the most pleasure from. The thing they like most about the RHS, is that they can dress-up and stand out, for which they feel rewarded by the positive attention from bystanders. 
Joyce: 'This is indeed part of the game, that if you're walking around in your fantastic outfit, everybody is looking at you. Everybody thinks it's great. (...) That is just the charisma of the clothes. And women my age [usually] don't get this attention, because we have become somewhat invisible, but then suddenly we are visible again.'

Janna: 'It just looks so joyful. And there are always people coming up to us asking 'what is this, what do you do?' Yeah, I think that's fun. It's not just that it cheers us up but very often others too. Occasionally someone says, pffff, ridiculous bunch (...), but usually people do cheer up when they see us.

Some Red Hatters connect their dressing up to what they enjoyed when they were young girls. Joyce says that: 'When I was little I always had birthday parties and then we had a big box with clothes and we'd all dress up. I did this until I was about thirteen and then nobody wanted to anymore. But it was the most fun thing ever. Dress up and play a different person, and now I play a person again, with the Red Hat' Some Hatters go one step further and stress transgression of the rules. Froukje, who is typified by her red hat with a short dotted veil in front, loose purple skirt, red boots and lace red gloves and has two RHS flags attached to the windows of her car, says, for instance

Froukje: 'But mostly I am still that little girl that wants to dress-up. When I read [the RHS manual] I thought this is me, because I am still this little girl. And I still like to be a bit naughty, because I still love playing 'ring and run.' Yes, I still do that. When I go out for dinner [with my husband] and I am wearing my red hat, then I still will always play ding dong ditch. My husband thinks it's terrible, hi hi hi. But his trick now is to condone it, and now the fun is gone.' 
Froukje also commemorates that she once whistled on her fingers during an event, after which her chapter members asked if she would teach them this neat trick as well. On a similar note Joyce says that she and the other Hatters often play games in which cheating is part of the fun: 'It is just over the top cheating, like a child' This is another dimension in the performance of the fun self by breaking the rules and going back to childhood pleasures.

From the interviews it, also became clear, however, that the liberation of the 'fun' self and the celebration of life were not simply brought about by the RHS membership. It was also articulated with particular events in their lives. Many of the women we talked with recounted how particular emotional events made them realise that life was short. Corrien, for instance, 'started to live more consciously', as she expressed it, after the death of a brother she was particularly close with. Similar stories of realising life's value against the odds of personal hardship were told by other respondents. We present two of those in the form of a mini-biography to further examine the relation between a particular life history and the enjoyment of Red Hat membership.

\section{Renee: Celebrating a Common Bond of Shared Life-Experiences}

In the winter of 2011 we met Renee, in the lobby of a hotel next to the university; she is a stately looking woman with half-long greyish-blond hair and wore a purple sweater on top of some blue jeans. A very different look - in spite of the purple of her sweater from when she goes out with the Red Hats as 'Queen Valentina'. Then she is completely in purple, wears a dress instead of trousers and, of course, a striking red hat. Renee feels it is important to honour this dress-code and, if possible, in a way that is chic. Like many 
Hatters, she owns more than one red hat: one for summer, one for winter, one for outside, one for inside. The last one is rather special, because it is very curly and kind of looks like a very big decoration you can find on a birthday gift.

At the time of our interview Renee was 65 years old. She grew up in the Netherlands during the rebuilding period that followed directly after WOII. As she explains this was a time in which 'as a girl you just did not count as much as a boy.' Renee had a brother who she said was always put first, which she thought was unfair. Still, she also praises how much opportunity her parents gave her, during this time, to give direction to her life.

They enabled her to go to school, work and to travel. When she was 17 Renee moved to London to become an au pair. Afterwards she lived abroad for several years. Renee has been married and divorced twice and had two sons. Her oldest son Mark passed away at the age of fourteen, after which she was - as she says - 'out of the world' for five years, suffering from regular anxiety attacks. Currently Renee lives in a flat for people over the age of fifty-five. She does not have a lot of money, but she negotiates the feelings of exclusion this sometimes brings about by claiming that life 'is not about what you have, but about who you are.'

In 2005 Renee read an article about the RHS in a Dutch national newspaper and decided to start a chapter. After some quarrels in her chapter in 2009 she quit being a Red Hatter, but later decided to re-enter with a smaller group of Hatters. Just like other Hatters, Renee stresses the fun factor of being with the Red Hats. For her this also means that the RHS 'needs to remain fun.' She also emphasizes that the RHS needs to add something to the life she already has and should not become the 'fulfilment' of that life. 
In explaining the RHS's main appeal to her, Renee made clear that she likes being in the company of women of the same mind and particularly argues that other Red Hatters can relate to her through their shared experiences of personal hardship. Being around women who she thinks share similar life histories produces comfort and understanding for her. When talking about the importance of shared life histories, Renee explains this in terms of the difference between Red Hatters and young people.

Renee: 'When you are of a certain age, you all have been through things. (...) And you don't have that with young people, because they still have to discover everything, they still have to experience everything. And you can well talk to them and work with them, but we [the Red Hatters] all have something and this brings comfort.'

Clearly, Renee's interest in this common bond of shared life-experiences is strongly influenced by her own experience of the loss of Mark, when she was forty-one herself.

When asked about periods of transition in her life Renee talked about how special it was for her to give birth to her first child. She explains how she felt 'at the height of [her] femininity' when she felt life inside of her for the first time.

Renee: 'Yes, when I became a mother for the first time. I thought that was very special. Also when I was pregnant and felt life for the first time. I always did consider the things I did for the first time to be very special. (...)

Renee: And my firstborn has also passed away. (...) That has had the biggest impact on my life. I lost grounds for five years. I can still cry over it. (...) It has been 23 years, or 24 in September, and I can still cry over it. Strange, isn't it?

Samira: Well I don't know about that. I don't think that's strange actually. 
Renee: And sometimes I would tell someone 'I'm over it,' but I'm not. (...) I've lost grounds for five years. Had anxiety attacks, I went through the deepest holes. But I've fought myself out and tried to have fun in my life again, to work and to do fun things.'

This interview extract shows in more detail how Renee felt the need to go back to a normal life. Other Hatters told similar stories of loss, and feeling the need for joy and ease. In these stories, the celebration and fun they find in the Red Hat Society derive meaning from their past experiences of personal hardship. While previous studies suggest that the RHS offers a resource for coping with these experiences, our findings suggest somewhat differently that one can only really recognize the value of simple fun if one has gone through loss and hardship.

\section{Annette: Celebration as Empowerment}

We introduced Annette earlier in this article as one of the first Red Hatters in the Netherlands. Her story demonstrates that while women over fifty may share difficult life experiences, this in no way implies their histories are similar. Particularly for women over fifty who do not have children or grandchildren, feelings of being marginalized and excluded do not only pertain to younger generations, but can also be felt within their own age and gender group. For them the concepts of celebration and fun often gain meaning in the sense of empowerment. This is for instance the case for Annette. Annette was 62 years old at the time we talked with her. She recalls she had a difficult youth. As an only child she did not feel particularly wanted by her mother, who she felt would rather have had a boy than a girl. Her parents were well off which made her the object of envy at her school, located in a typically Dutch orthodox protestant environment. However, she 
herself would not have minded to swap the money for a happier childhood. Annette has been married twice. Her current husband is her second and they never had children.

Annette learned about the RHS in 2005 through a broadcast by a Dutch news channel. ${ }^{9}$ Her husband was watching and called her out of the kitchen, shouting 'Annette, Annette! Come and have a look, this is fun! This is something for you!' Initially she joined an existing chapter, but soon decided to start her own. Her chapter consists of over 55 Hatters and is rather large compared to others. Annette's husband is very supportive of her RHS membership and together they maintain the Dutch national RHS web-page. Like Renee, Annette also explains she derives pleasure from the ties with other women she met as a Red Hatter. Unlike Renee, however, this pleasure is not so much produced from the idea that women over fifty have similar life experiences. In the interview, Annette more than once expressed feelings of being left out by women with other life histories e.g., women who, unlike herself, have children and grandchildren. According to her these women have other interests than she. Consider, for instance, the following fragment.

Annette: 'You have been friends with someone for years, and her children are also getting children (...). Granny has to baby sit. And when in the past you would just have a lovely day going to town, now you have to go into town and look for baby- or children's outfits. And that's just different. No more going together to a fashion store or shoe store, having a good laugh, and try on everything (...). And that friendship wears of, that's very weird, but it's because you don't share the same interests anymore.'

Often Annette also employs a more general discourse of rebellion against the marginalization of older women in Western society. In the interview she, for instance, 
discussed women who become widowed and are suddenly viewed as femme fatales. She discussed how (again other) women her age are not allowed to use the home computer by their husbands and that the RHS helps them to broaden their lives. Moreover, she views the RHS as a movement that resists the dominant position of youth culture, signifying to others that midlife and older women 'don't have to [be] put out with the garbage yet.'

For Annette celebration and fun in the RHS hence become meaningful as an act of rebellion and empowerment. She exclaims: 'Our hat is our freedom!' The hat and the fun it embodies for her mean liberation from cultural restriction. This idea is most clearly expressed in the following quote, in which Annette discusses feelings of constraint while growing up.

Annette: 'But mind you, if you would be out of sync. [makes sound of a bang]. (...) very sneaky you would do things, now and then. [But mostly] you did not dare to. And now I think, uh-oh, yippie, go for it, put on your red hat and have fun. ${ }^{10}$ I mean, when I was sixteen I would not have dared to wear a red hat, that would have been hit squarely off my head [by her mother]. And now I wear it with verve, brilliant! (...) Because in the past I did not dare to do anything deviant. Because I had to be the good young girl.'

Annette's story also shows an experience of constraint and liberation of the 'fun' self from cultural restriction. It simultaneously shows, however, how some red Hatters see such a performance of the 'fun' self as an act of rebellion and how particular life histories of women over fifty feed into this rebellion. In Annette's case this rebellious sense of fun is motivated in specific past and present feelings of marginalization, restriction and exclusion. Those feelings were also present in other interviews, particularly with Hatters 
without children and spouses. One of them even founded a Single Society within the RHS to negotiate feelings of exclusion and marginalization by her married peers.

\section{Conclusion and Discussion}

In this paper we explored the 'fun' factor in being member of the RHS in the Netherlands. Though this country differs sufficiently from the US in terms of its gender culture (Hofstede, 1984), our results still in many ways mirror those found in previous studies about the RHS. Such studies have typically interpreted the various practices distinctive of Red Hatters as negotiating hegemonic femininity alongside experiences of personal hardship. The latter type of negotiation is better known as 'coping'. Based on an analysis of in-depth interviews with Dutch Red Hatters we located these negotiating practices within a broader performance of the 'fun' self, in which both the psychological and cultural meanings of RHS performance are connected. More in particular our study showed that, Red Hatters attribute great importance to celebrating life and having a fun time.

This performance of the 'fun' self is typically articulated around feelings of constraint and liberation. The causes of such constraints are diverse. Some emerge from dominant cultural conceptions of femininity and age, which tend to marginalize, exclude and restrict midlife and older women in Western society. Others are produced from diverse experiences of personal hardship. Our analysis also shows, however, that in all cases experiences of constraint are located in the specific and situated life histories of Hatters. Hence, it is important to include an analysis of life histories in studies on gender and identity performance. Instead of providing a general theory, life histories help 
contextualize such performances and thus provide insight into the different motivations and meanings that inspire them.

Because of the long list of constraints to the 'fun' self that is articulated in Hatters' stories, also by those we have studied, it is no wonder that the RHS itself has also been approached more specifically as a coping resource. Many of the previous studies about the RHS have attempted to explicate those aspects that help women over fifty cope with stressful situations in their lives (see for instance, Sun et al., 2007; Hutchinson et al., 2008; Radina et al., 2008). In some of these studies the concepts of fun and celebration are made subordinate to certain 'higher' psychological and social goals, such as coping and well-being. According to our analysis of Red Hatters accounts, however, this is reversed, that is, coping and well-being serve the goal of celebrating life. Experiences of hardship have made them realize the importance of having fun, something they can now fully appreciate. In other words Red Hatters accounts suggest that: 'celebration is the mainstay of our survival, and "coping" and "making do" are mere ways of getting over the obstacles to celebrating.' (Johnson, 1983: 76, based on a discussion of the work of black feminist poet Lucille Clifton).

Our interviews suggest that Hatters do not generally wallow in the sorrows of their lives. Instead they celebrate those things they are supposed to feel sorrow for (cf. Rashedi, 2011). They celebrate their femininity and their age, while on the face of everything the female ageing process is still viewed as a defect in Western society (see Greer, 1991). However, as Red Hatters also sometimes put it: 'To be unwanted is also to be free' (Greer, 1991: 6). Through this performance of radical femininity Red Hatters' public engagement in fun also becomes a negotiation of hegemonic femininity (cf. 
Yarnal, 2006; Stalp et al., 2008; 2009). Whether they themselves also view their performance as empowering is, however, not self-evident, but highly depended upon the discourses they construct around past and present life-experiences. 


\section{Notes}

${ }^{1}$ All information derived from interviews with key RHS members and the study of relevant RHS websites (Van Bohemen, 2011)

${ }^{2}$ This article is part of a larger study on the RHS in the Netherlands, in which ethnographic data is collected and triangulated from different sources: interviews and observations. The latter have been collected through participation in a number of RHS events, such as the Queens lunch, the RHS national day and two regional meetings. Furthermore, the interviews themselves are also treated as ethnographic material, especially since some respondents have met us for an interview in full Red Hat regalia.

${ }^{3}$ All information from http://www.redhatsociety.com

${ }^{4}$ Article in the NRC (Tracey Metz: February 26, 2005)

${ }^{5}$ All information derived from a combination of interviews, observation and web research (Van Bohemen, 2011).

${ }^{6}$ Redtekehat is the name of the Dutch RHS choir. The title is a pun on the Dutch word retteketet, an expression of fun.

${ }^{7}$ http://www.redhatsociety.com/aboutus/howitstarted.html, visited 01-09-2010.

${ }^{8}$ The original Dutch word that Janna used is 'gezellig', a notoriously untranslatable term which indicates an experience of friendship, fun, homeliness, togetherness, but also uncomplicated or easy, as later in this quote.

${ }^{9}$ Broadcast in Een Vandaag, a Dutch news program that follows directly after the popular 6 o'clock news.

${ }^{10}$ Annette uses the expression: 'Gezellig de rode hoed op', 


\section{References}

Berger, J. (1973) Ways of Seeing. London: The British Broadcasting Corporation.

Brannen, J. and Nilsen, A. (2011) 'Comparative Biographies in Case-based Crossnational Research: Methodological Considerations', Sociology 45(4): 603-618.

Butler, J. (1988) 'Performative Acts and Gender Constitution: An Essay in Phenomenology and Feminist Theory', Theatre Journal (Washington, D.C.) 40(4): $519-531$.

Butler, J. (1990) Gender Trouble: Feminism and the Subversion of Identity. New York: Routledge.

Chase, S. E. (2005) 'Narrative Inquiry: Multiple Lenses, Approaches, Voices', in N. K. Denzin and I. S. Lincoln (eds.) The Sage Handbook of Qualitative Research (3rd ed., pp. 651-679). Thousand Oaks; London; New Delhi: Sage Publications.

Glaser, B.G. and Strauss, A.L. (1967) The Discovery of Grounded Theory. Chicago: Aldine.

Cooper, S.E. (2004) The Red Hat Society: Fun and Friendship After Fifty. New York: Warner Books.

Greer, G. (1991) The Change: Women, Ageing and the Menopause. Fawcett Columbine; New York: Ballantine Books.

Hofstede, G. (1984) Culture's Consequences: International Differences in Work-Related Values (2nd ed.). Beverly Hills CA: $\underline{\text { Sage. }}$

Hutchinson, S. L., Yarnal, C. M., Staffordson, J. and Kerstetter, D. L. (2008) 'Beyond Fun and Friendship: The Red Hat Society as a Coping Resource for Older Women', Ageing and Society 28(07): 979-999. 
Johnson, J. (1983) 'The Theme of Celebration in Lucille Clifton's Poetry', Pacific Coast Philology 18(1): 70-76.

Radina, M. E., Lynch, A., Stalp, M. C. and Manning, L. K. (2008) '"When I Am an Old Woman, I Shall Wear Purple": Red Hatters Cope with Getting Old', Journal of Women \& Aging 20(1): 99-114.

Rashedi, R. (2011) 'Masculine versus Feminine Eros: Sisterly Communities or Divisions?', Predicate: An English Studies Annual 1(1): 118-138.

Son, J. S., Kerstetter, D. L., Yarnal, C. M. and Baker, B. L. (2007) 'Promoting Older Women's Health and Well-Being through Social Leisure Environments: What We Have Learned from the Red Hat Society®', Journal of Women \& Aging 19(3): 89104.

Stalp, M. C., Radina, M. E. and Lynch, A. (2008) '"We Do It Cuz It's Fun": Gendered Fun and Leisure for Midlife Women through Red Hat Society Membership', Sociological Perspectives 51(2): 325-348.

Stalp, M. C., Williams, R., Lynch, A. and Radina, M. E. (2009) 'Conspicuously Consuming: The Red Hat Society and Midlife Women's Identity', Journal of Contemporary Ethnography 38(2): 225-253.

Van Zoonen, L. (1994) Feminist Media Studies. Thousand Oaks; London; New Delhi: Sage Publications.

Yarnal, C. M. (2006) 'The Red Hat Society ${ }^{\circledR}$ : Exploring the Role of Play, Liminality, and Communitas in Older Women's Lives', Journal of Women \& Aging 18(3): 5173. 
Yarnal, C. M., Chick, G. and D.L. Kerstetter (2008) '"I Did Not Have Time to Play Growing Up... So This is My Play Time. It's the Best Thing I Have Ever Done for Myself": What is Play to Older Women?', Leisure Sciences 30(3): 235-252.

Yarnal, C. M., Son, J. and Liechty, T. (2011) "'She Was Buried in Her Purple Dress and Her Red Hat and All of Our Members Wore Full 'Red Hat Regalia' to Celebrate Her Life": Dress, Embodiment and Older Women's Leisure: Reconfiguring the Ageing Process.' Journal of Aging Studies 25(1): 52-61. 


\section{Appendix 1}

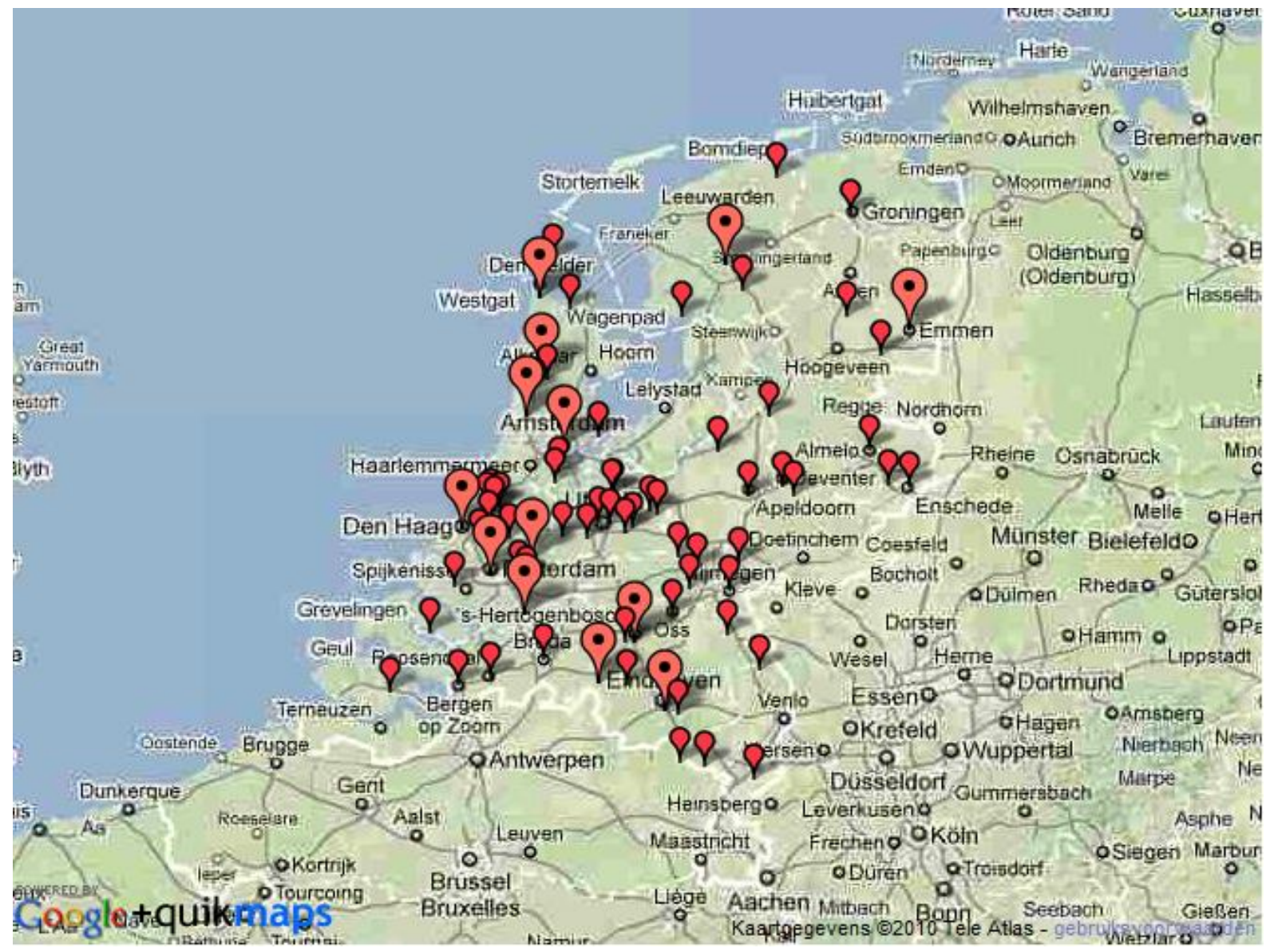

